\title{
POTENSI Bacillus spp. DARI RIZOSFER TANAMAN KEDELAI UNTUK MENGENDALIKAN PENYAKIT REBAH KECAMBAH (Sclerotium rolfsii Sacc.)
}

\section{Popi Oktania*, Husda Marwan dan Asniwita}

Jurusan Agroekoteknologi Fakultas Pertanian, Universitas Jambi

Jl. Raya Jambi - Ma. Bulian KM.15 Mendalo Darat, 36136

popioktania2@gmail.com (*Penulis untuk korespondensi)

\begin{abstract}
Abstrak
Bacillus merupakan rizobakteri yang dapat menghambat patogen tanaman dengan mekanisme antagonis berupa antibiosis. Bacillus spp. dapat mengendaliakan penyakit rebah kecambah yang disebabkan oleh Sclerotium rolfsii pada tanaman kedelai. Penelitian ini bertujuan untuk mendapatkan isolat bakteri Bacillus spp. dari rizosfer tanaman kedelai untuk mengendalikan penyakit rebah kecambah pada tanaman kedelai. Pelaksanaan pengujian bakteri dilakukan secara in vitro dan in planta. Pengujian secara in planta menggunakan Rancangan Acak Lengkap dengan 14 perlakuan terdiri atas 2 perlakuan kontrol (sehat dan sakit), 1 perlakuan menggunakan fungisida, dan 11 perakuan menggunakan isolat bakteri Bacillus spp. Hasil pengujian menunjukan bahwa perlakuan bakteri Bacillus spp. berpengaruh nyata terhadap persentase rebah kecambah. Terdapat beberapa isolat mampu menekan penyakit rebah kecambah sebelum muncul kepermukaan tanah dan semua bakteri Bacillus spp. mampu menekan penyakit rebah kecambah setelah muncul kepermukaan tanah pada tanaman kedelai.
\end{abstract}

Kata kunci : rizobakteri, Bacillus spp., penyakit rebah kecambah, Sclerotium rolfsii.

\section{PENDAHULUAN}

Tanaman kedelai merupakan salah satu komoditi yang penting di Indonesia (Adisarwanto, 2008). Menurut Badan Pusat Statistik (2016), Produktivitas kedelai Provinsi Jambi pada tahun 2015 sebesar 1,372 ton/ha. Produktivitas ini masih dibawah produktivitas nasional yaitu sebesar 1,569 ton/ha.

Salah satu penyebab rendahnya produktivitas kedelai dapat disebabkan oleh penyakit. Penyakit rebah kecambah (damping off) merupakan salah satu penyakit penting bagi tanaman kedelai dan jenis kacang-kacangan lainnya seperti kacang tanah dan kacang hijau di Indonesia, penyakit tersebut dapat menyebabkan kehilangan hasil hingga $100 \%$ (Sastrahidayat et al., 2007).

Pengendalian dengan cara biologi merupakan salah satu upaya untuk mengendalikan penyakit rebah kecambah yang ramah lingkungan. Pengendalian tersebut menggunakan bakteri antagonis dari rizosfer tanaman. Bakteri yang hidup dalam sistem perakaran tanaman dan memberikan keuntungan bagi tanaman dikenal sebagai Plant 
Growth Promoting Rhizobacteria (PGPR).

Menurut penelitian yang dilakukan oleh Abidin et al. (2015) bahwa perlakuan bakteri antagonis Bacillus sp. dan Pseudomonas sp. mampu menghambat pertumbuhan cendawan patogen $S$. rolfsii secara in vitro. Hasil penelitian tersebut menunjukkan bahwa, persentase penghambatan bakteri

Bacillus sp. (UB-ABS1) terhadap S. rolfsii secara in vitro pada 2 hsi, 3 hsi, dan 4 hsi yaitu sebesar 19,96\%, 41,73\%, 52,83\%. Hasil penelitian yang dilakukan oleh Nawangsih et al. (2014) menyatakan bahwa Isolat bakteri TP-32 merupakan bakteri tahan panas yang diisolasi dari rizosfer kedelai pada sistem PHT- Biointensif memiliki persentase penghambatan terhadap S. rolfsii secara in vitro sebesar 95,6\%.

Penelitian ini bertujuan untuk memperoleh isolat Bacillus spp. dari rizosfer kedelai yang berpotensi untuk mengendalikan penyakit rebah kecambah yang disebabkan oleh patogen $S$. rolfsii pada tanaman kedelai.

\section{BAHAN DAN METODE}

Penelitian ini dilaksanakan di Laboratorium Penyakit Tanaman dan Rumah Kaca Fakultas Pertanian Universitas Jambi dari bulan November 2016 sampai dengan September 2017.

Bahan-bahan yang digunakan dalam penelitian ini adalah tanah dari rizosfer tanaman kedelai, isolat cendawan S. rolfsii koleksi laboratorium, benih kedelai varietas Anjasmoro, media tanam (tanah, pupuk kandang, pasir) steril, alkohol 70\%, $\mathrm{NaClO} \mathrm{2 \% ,}$ akuades steril, plastik tahan panas, plastik, spritus, kapas, kertas label, polybag, fungisida bahan aktif Mankozeb, media Potato Dextrose Agar (PDA), media Tryptic Soy Agar (TSA) dan media Corn Meal Sand (CMS). Alat-alat yang digunakan adalah termometer, autoclave, laminar air flow, cawan petri, gelas piala, kompor, timbangan digital, timbangan, lampu bunsen, jarum oose, object glass, cover glass, vortex, glass beads, erlenmeyer, hands sprayer, mortal, bak plastik (41 x $32 \mathrm{~cm})$, mikropipet, tisu, spidol, pena, buku tulis dan kamera.

Metode penelitian meliputi uji penghambatan pertumbuhan S. rolfsii secara in vitro dan uji penekanan penyakit rebah kecambah pada tanaman kedelai dengan isolat bakteri Bacillus spp 


\section{Pelaksanaan Penelitian}

\section{Isolasi bakteri Bacillus spp. dari rizosfer tanaman kedelai}

Sampel tanah diambil dengan metode purposive sampling. Sampel tanah diambil dari rizosfer beberapa varietas kedelai di lokasi yang berbeda. Varietas Anjasmoro (SA) diambil dari Desa Sebapo Kec. Mestong, Varietas Lokal 1 (SM) di Desa Suka Makmur Kec. Muara Jambi, Varietas Dega (G1), Dena 2 (G2), Varietas Anjasmoro (G3) dan Varietas Dena 1(G4) di Desa Kota Baru Kec. Geragai dan Varietas Lokal 2 (KK) di Kota Kandis Kec. Dendang.

Sampel tanah diambil sebanyak lima titik pada setiap varietas dengan jarak yang berbeda-beda, masing-masing titik diambil sekitar $0,5 \mathrm{~kg}$ tanah pada kedalaman tanah 15 $30 \mathrm{~cm}$. Kemudian sampel tanah dikering anginkan dan ditumbuk dengan mortal. Sampel tanah tersebut masing-masing diambil sebanyak $100 \mathrm{~g}$ dan dikompositkan sehingga didapatkan $500 \mathrm{~g}$ tanah, setelah itu dimasukkan ke kantung plastik.

Sebanyak $10 \mathrm{~g}$ tanah sampel disuspensikan pada $90 \mathrm{ml}$ air steril dalam erlenmeyer dan dishaker dengan kecepatan $150 \mathrm{rpm}$ selama 30 menit (Khaeruni et al., 2010). Isolasi bakteri Bacillus spp. menggunakan metode Eliza et al. (2007) yang telah dimodifikasi. Suspensi sampel dilakukan pengenceran berseri $10^{-1}-10^{-9}$, kemudian masing-masing suspensi pengenceran $10^{-1}, 10^{-3}, 10^{-5}, 10^{-7}$ dan $10^{-9}$ dikocok dan dipanaskan di dalam penangas air pada suhu $75-80{ }^{\circ} \mathrm{C}$ selama 10 menit. Sebanyak $100 \mu \mathrm{l}$ suspensi diteteskan pada media tryptic soy agar (TSA), kemudian diratakan menggunakan glass beads. Selanjutnya diiinkubasi selama 3 hari dan dilihat koloni yang tumbuh. Koloni yang tumbuh dengan ciri-ciri koloni yaitu umumnya berwarna putih sampai kekuningan atau putih suram, tepi koloni pada umumnya tidak rata, permukaannya kasar dan tidak berlendir, beberapa koloni ada yang cenderung kering bubuk, koloni besar dan tidak mengkilat (Hatmanti, 2000).

\section{Isolasi cendawan Sclerotium rolfsii}

Isolat $S$. rolfsii koleksi Laboratorium Penyakit Tanaman diinokulasi ke tanaman kedelai. Reisolasi cendawan dilakukan dengan cara mengambil sklerotia dari S. rolfsii yang tumbuh disekitar tanaman kedelai dan ditumbuhkan pada media PDA. Biakan diinkubasi selama 4-5 hari sampai miselium tumbuh dan memenuhi permukaan cawan. Kemudian diidentifikasi menggunakan buku Barnett (1960) dan dibuat stok inokulum. 


\section{Uji daya hambat Bacillus spp. terhadap S. rolfsii secara in vitro}

Pengujian daya hambat isolat bakteri terhadap $S$. rolfsii pada media PDA dilakukan dalam dua tahap. Pada uji tahap pertama, potongan biakan $S$. rolfsii berdiameter $0,5 \mathrm{~cm}$ diinokuasikan ditengah cawan petri, kemudian 4 isolat Bacillus spp. digores memanjang (2 $\mathrm{cm}$ ) dengan jarak $1 \mathrm{~cm}$ dari tepi cawan (Gambar 1). Aktivitas penghambatan diamati secara kualitatif berdasarkan adanya zona hambat yang terbentuk disekitar koloni bakteri (Astuti, 2007). Pengamatan dilakukan pada 2 hari setelah inokulasi (hsi). Isolat bakteri yang menunjukkan adanya zona hambat selanjutnya diuji terhadap $S$. solfsii dengan metode uji ganda.

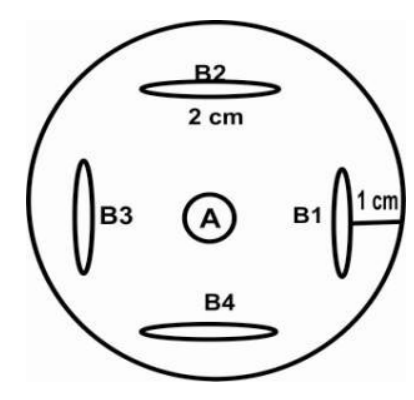

Gambar 1. Skema pengujian daya hambat isolat bakteri terhadap S. rolfsii pada tahap pertama : (A) koloni $S$. rolfsii; $\left(\mathrm{B}_{1}-\mathrm{B}_{4}\right)$ Isolat bakteri.

Uji ganda dilakukan dengan menggoreskan isolat bakteri berjarak $3 \mathrm{~cm}$ dari tepi cawan pada media PDA dan $3 \mathrm{~cm}$ dari koloni cendawan $S$. rolfsii berdiameter $0,5 \mathrm{~cm}$ (Gambar 2). Miselia cendawan yang digunakan umur 5-7 hari dan koloni cendawan masih aktif tumbuh. Biakan diinkubasi pada suhu ruang selama 3 x 24 jam dan dilakukan pengamatan pada $2 \times 24$ jam dan 3x24 jam.

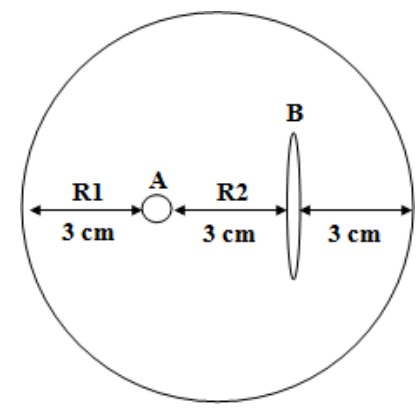

Gambar 2. Skema uji ganda isolat bakteri terhadap S. rolfsii : (A) koloni S. rolfsii; (B) Isolat bakteri; (R1) Jari-jari koloni $S$. rolfsii yang menjauhi koloni bakteri; (R2) Jari-jari koloni $S$. rolfsii yang mendekati koloni bakteri. 
Pengamatan dilakukan dengan mengukur jari-jari koloni cendawan S. rolfsii.

Persentase daya hambat bakteri terhadap $S$. rolfsii dihitung menggunakan rumus sebagai berikut :

$$
\mathrm{I}=\frac{R 1-R 2}{R 1} \times 100 \%
$$

Keterangan :

I $\quad=$ Persentase daya hambat $(\%)$

R1 = Jari-jari koloni $S$. rolfsii yang menjauhi koloni bakteri R2 = Jari-jari koloni $S$. rolfsii yang mendekati koloni bakteri

\section{Uji in planta Bacillus spp. terhadap penyakit rebah kecambah}

Uji in planta dilakukan dengan menggunakan Rancangan Acak Lengkap (RAL) dengan perlakuan yang digunakan yaitu 11 isolat Bacillus spp. yang memiliki daya hambat tinggi terhadap $S$. rolfsii pada uji in vitro, 2 perlakuan kontrol (sehat dan sakit), 1 perlakuan fungisida dan setiap perlakuan diulang sebanyak 3 kali.

\section{Persiapan media tanam}

Media tanam yang digunakan adalah pasir, tanah yang telah diayak, dan pupuk kandang. Perbandingan dosis pasir, tanah, dan pupuk kandang adalah 2:1:1 (v:v:v). Sebelum dimasukan kedalam bak plastik, media tanam terlebih dahulu disterilkan dengan metode Tyndalisasi. Kemudian media diinkubasikan selama 1 minggu sebelum dipergunakan. Campuran media tanam tersebut dimasukan ke dalam bak plastik berukuran $41 \mathrm{x} 32 \mathrm{~cm}$ dan masing-masing di isi dengan $5 \mathrm{~kg}$ media tanam.

\section{Pengujian daya kecambah benih}

Uji daya kecambah benih dilakukan dengan metode Blotter, sebanyak 100 benih sampel kedelai diambil secara acak. Selanjutnya didesinfektan dengan larutan $\mathrm{NaClO} 2 \%$ selama 2 menit dan dibilas dengan air steril. Benih dimasukan ke dalam cawan petri yang dialasi dengan 5 lembar kertas saring yang sudah dibasahi dengan akuades. Setiap cawan petri diletakan sebanyak 10 benih kedelai dengan jarak yang sama dengan jarak yang sama. Pengujian dilakukan selama 7 hari. Kemudian dihitung persentase daya kecambah dengan rumus :

Persentase daya kecambah $=\frac{\text { Jumlah benih yang berkecambah }}{\text { Jumlah benih yang dikecambahkan }} \times 100 \%$ 


\section{Perbanyakan cendawan $S$. rolfsii dan aplikasi ke media tanam}

Cendawan S. rolfsii diperbanyak menggunakan media Corn Meal Sand (CMS) dengan menggunakan perbandingan $98 \%$ pasir, $2 \%$ tepung jagung dan ditambahkan $20 \%$ akuades. Infestasi cendawan $S$. rolfsii dilakukan dengan cara mencampur satu kantong plastik cendawan $S$. rolfsii yang dibiakan pada media CMS (50 g) kedalam media tanam dan diaduk sampai kedalaman $5 \mathrm{~cm}$ dari permukaan tanah. Selanjutnya diinkubasikan selama 1 minggu sebelum tanam.

\section{Perbanyakan bakteri Bacillus spp. dan aplikasi suspensi bakteri ke media tanam}

Isolat Bacillus spp. yang terpilih dibiakan dalam media TSA dan diinkubasi selama 2 x 24 jam, selanjutnya sel bakteri dipanen dengan cara menambahkan $5 \mathrm{ml}$ akuades ke dalam cawan petri dan digores menggunakan jarum oose. Bakteri dibiakan pada media pepton 5\% dan di inkubasikan pada inkubator bergoyang selama 72 jam. Konsentrasi suspensi diatur dengan menggunakan spectrofotometer hingga menjadi $10^{9}$ $\mathrm{cfu} / \mathrm{ml}\left(\mathrm{OD}_{600}=0,16\right)$ yang selanjutnya digunakan sebagai inokulum untuk aplikasi bakteri antagonis (Thompson, 1996).

Benih kedelai disterilisasi permukaan dengan menggunakan $\mathrm{NaClO} 2 \%$ dan direndam selama 2 menit, selanjutnya dibilas dengan akuades sebanyak 3 kali. Aplikasi bakteri Bacillus spp. dilakukan dua tahap yaitu dengan merendam benih kedelai dan penyiraman suspense bakteri pada media tanam. Tahap pertama, benih direndam dalam $100 \mathrm{ml}$ suspensi bakteri dengan kerapatan $10^{\circ} \mathrm{cfu} / \mathrm{ml}$ selama 6 jam, lalu benih dikering anginkan, selanjutnya ditanam dalam wadah yang telah disediakan (Khaeruni dan Rahman, 2012). Tahap kedua, ketika benih ditanam dilakukan penyiraman suspensi bakteri pada setiap lubang tanam dengan volume $15 \mathrm{ml}$ dengan kerapatan $10^{\circ} \mathrm{cfu} / \mathrm{ml}$ (Abidin et al., 2015). Untuk perlakuan kontrol benih direndam dalam akuades steril selama 6 jam.

\section{Penanaman dan pemeliharan tanaman}

Benih kedelai yang digunakan yaitu benih yang memiliki ukuran relatif sama besar, bebas dari kerusakan karena mekanis dan benih yang telah diberi perlakuan perendaman suspensi bakteri. Sebanyak 30 benih yang sudah diberi perlakuan ditanam pada masing-masing wadah kecambah dengan jarak tanam 10 x $4 \mathrm{~cm}$. Pemeliharaan tanaman dilakukan dengan melakukan penyiraman settiap hari pada pagi atau sore. 


\section{Parameter pengamatan}

Persentase kecambah terserang sebelum muncul ke permukaan tanah (preemergence damping off)

Persentase kecambah terserang dihitung berdasarkan jumlah kecambah yang tidak muncul ke permukaan tanah sampai tanaman berumur 1 minggu.

Kecambah yang tidak muncul dilakukan pembongkaran dan pengamatan terhadap kecambah yang tidak sakit. Persentase kecambah terserang sebelum muncul ke permukaan tanah (Pre-emergence damping off) dapat dilakukan menggunakan rumus:

$$
\mathrm{S}=\frac{\mathrm{A}-\mathrm{B}}{\mathrm{A}} \times 100 \%-(100 \%-\mathrm{D})
$$

Keterangan : $\mathrm{S}=$ persentase terserang sebelum muncul ke permukaan tanah (Preemergence damping off)

$\mathrm{A}=$ jumlah benih yang ditanam

$\mathrm{B}=$ jumlah kecambah yang muncul ke permukaan tanah $\mathrm{D}=$ persentase daya kecambah benih

\section{Persentase kecambah terserang setelah muncul kepermukaan tanah (Post-} emergence damping off)

Pengamatan kecambah terserang setelah muncul kepermukaan tanah dilakukan setiap hari setelah kecambah muncul ke permukaan tanah sampai tanaman berumur 2 minggu. Persentase kecambah yang terserang dapat dihitung dengan rumus :

$$
\mathrm{K}=\frac{\mathrm{n}}{\mathrm{N}} \times 100 \%
$$

Keterangan : $\mathrm{K}=$ persentase kecambah terserang setelah muncul ke permukaan tanah (post emergence damping off)

$\mathrm{n}=$ jumlah kecambah terserang setelah muncul ke permukaan tanah (postemergence damping off)

$\mathrm{N}=$ jumlah benih yang muncul

\section{Penekanan penyakit rebah kecambah}

Persentase penekana penyakit rebah kecambah dapat dihitung dengan menggunakan rumus sebagai berikut : 


$$
\mathrm{PP}=\frac{\mathrm{lk}-\mathrm{li}}{\mathrm{lk}} \times 100 \%
$$

Keterangan : $\mathrm{PP}=$ penekanan penyakit

$\mathrm{lk}=$ intensitas penyakit pada tanaman kontrol sakit $\mathrm{li}=$ intensitas penyakit pada perlakuan ke $i$.

\section{Analisis data}

Data hasil pengamatan penghambatan Bacillus spp. terhadap S. rolfsii dianalisis secara deskriptif. Data hasil pengamatan daya hambat dual kultur secara in vitro dan pengamtan in planta dianalisis untuk mengetahui pengaruh perlakuan dengan menggunakan analisis ragam dan dilanjutkan dengan uji DMRT (Duncan Multiple Range Test) pada taraf $5 \%$.

\section{HASIL DAN PEMBAHASAN}

\section{Hasil}

\section{Uji penghambatan bakteri Bacillus spp. terhadap pertumbuhan koloni S. rolfsii}

Hasil isolasi bakteri dari rizosfer tanaman kedelai diperoleh 120 isolat Bacillus spp.dan terdapat 51 isolat yang mampu menghambat pertumbuhan patogen $S$. rolfsii secara in vitro (Lampiran 3). Berdasarkan pengamatan secara kualitatif terdapat 17 isolat bakteri yang memiliki zona bening lebih besar dari jumlah keseluruhan isolat yang mampu menghambat $S$. rolfsii. Hasil persentase daya hambat bakteri Bacillus spp. terhadap $S$. rolfsii secara in vitro menunjukkan bahwa rata-rata kemampuan daya hambat bakteri dibawah 50\% (Tabel 1).

Persentase daya hambat Bacillus spp. terhadap S. rolfsii secara in vitro antara 39,45\% sampai 55\%. Hasil evaluasi persentase daya hambat Bacillus spp. terhadap S. rolfsii terdapat 11 isolat yang digunakan untuk uji in planta di rumah kaca. Isolat tersebut terdiri atas 3 isolat Varietas Anjasmoro, 4 isolat Varietas Dena 1, 3 isolat Varietas Lokal 1 dan 1 isolat Varietas Dena 2 . 
Tabel 1. Persentase daya hambat Bacillus spp. terhadap S. rolfsii secara in vitro

\begin{tabular}{lc}
\hline Isolat Bakteri & Daya Hambat (\%) \\
\hline B.G1-3 & 45,27 \\
B.G1-4 & 41,38 \\
B.G3-10 & 44,70 \\
B.G3-20 & 45,23 \\
B.G3-27 & 55,00 \\
B.G4-3 & 39,88 \\
B.G4-4 & 45,25 \\
B.G4-5 & 41,35 \\
B.G4-6 & 46,59 \\
B.G4-7 & 45,93 \\
B.G4-15 & 39,45 \\
B.G4-18 & 42,04 \\
B.G4-19 & 39,90 \\
B.SM-2 & 45,00 \\
B.SM-4 & 48,44 \\
B.SM-15 & 42,70 \\
B.SM-16 & 40,60 \\
\hline
\end{tabular}

\section{Persentase pree-emergence damping off}

Berdasarkan hasil analisis ragam dari persentase pree-emergence damping off pada tanaman kedelai, menunjukkan bahwa perlakuan bakteri Bacillus spp. dan kontrol sakit tidak berbeda nyata.

Tabel 2. Persentase pree-emergence damping off dengan pemberian bakteriBacillus spp. pada tanaman kedelai

\begin{tabular}{lccc}
\hline Perlakuan & \multicolumn{2}{c}{ Pree-emergence damping off $(\%)$} & Penekanan Penyakit (\%) \\
\hline Kontrol sehat & & $0,00 \mathrm{a}$ & $*$ \\
Kontrol sakit & $51,56 \mathrm{bcde}$ & & 73,28 \\
Fungisida & & $13,78 \mathrm{a}$ & 21,56 \\
B.G3-10 & $40,44 \mathrm{bcde}$ & & $*$ \\
B.G3-20 & $47,11 \mathrm{bcde}$ & & $*$ \\
B.G3-27 & & $57,11 \mathrm{de}$ & $*$ \\
B.G4-4 & $54,89 \mathrm{cde}$ & & $*$ \\
B.G4-6 & & $59,33 \mathrm{e}$ & 23,71 \\
B.G4-7 & $39,33 \mathrm{bcd}$ & & 15,09 \\
B.G4-18 & $43,78 \mathrm{bcde}$ & & 34,49 \\
B.SM-2 & & $33,78 \mathrm{~b}$ & $*$ \\
B.SM-4 & $51,56 \mathrm{bcde}$ & & 34,49 \\
B.SM-15 & & $33,78 \mathrm{~b}$ & 30,18 \\
B.G1-3 & & $36,00 \mathrm{bc}$ & $\mathrm{bc}$ \\
\hline
\end{tabular}

Keterangan : Angka yang diikuti huruf yang sama menunjukkan tidak berbeda nyata berdasarkan uji Duncan Multiple Range Test pada taraf 5\%.*= tidak terjadi penekanan penyakit 
Namun berbeda nyata terhadap kontrol sehat dan fungisida. Isolat B.SM-2 dan B.SM-15 memiliki presentase penyakit terendah sebesar 33,78\% dan penekanan penyakit tertinggi sebesar 34,49\% dibandingkan dengan isolat lainnya (Tabel 2).

\section{Persentase post-emergence damping off}

Hasil analisis sidik ragam terhadap persentase post-emergence damping off menunjukkan bahwa perlakuan bakteri Bacillus spp. berpengaruh nyata terhadap kontrol (Tabel 3). Pemberian bakteri Bacillus spp. dapat menekan penyakit post- emergence damping off sebesar 35,16\% sampai 77,06\%.

\section{Pembahasan}

Bakteri Bacillus spp. tergolong memiliki mekanisme antagonis berupa antibiosis terhadap cendawan patogen. Hal tersebut ditandai dengan adanya zona hambat di sekitar koloni bakteri. Eliza et al. (2007) menyatakan bahwa senyawa antifungal yang dihasilkan oleh bakteri secara umum mengakibatkan terjadinya pertumbuhan yang abnormal pada hifa (malformasi), yang ditunjukkan dengan pembengkakan dan pemendekan hifa yang mengakibatkan hifa tidak dapat berkembang dengan sempurna.

Tabel 3. Persentase post-emergence damping off dengan pemberian bakteri Bacillus spp. pada tanaman kedelai

\begin{tabular}{lcc}
\hline Perlakuan & Post-emergence damping off $(\%)$ & Penekanan Penyakit $(\%)$ \\
\hline Kontrol sehat & $0,00 \mathrm{a}$ & $*$ \\
Kontrol sakit & $56,94 \mathrm{e}$ & $*$ \\
Fungisida & $10,91 \mathrm{~b}$ & 80,84 \\
B.G3-10 & $22,86 \mathrm{bc}$ & 59,85 \\
B.G3-20 & $22,02 \mathrm{bc}$ & 61,33 \\
B.G3-27 & $27,82 \mathrm{~cd}$ & 51,14 \\
B.G4-4 & $21,76 \mathrm{bc}$ & 61,73 \\
B.G4-6 & $36,92 \mathrm{~d}$ & 35,16 \\
B.G4-7 & $16,23 \mathrm{bc}$ & 71,50 \\
B.G4-18 & $16,93 \mathrm{bc}$ & 70,27 \\
B.SM-2 & $18,35 \mathrm{bc}$ & 67,77 \\
B.SM-4 & $15,6 \mathrm{bc}$ & 72,60 \\
B.SM-15 & $23,54 \mathrm{bc}$ & 58,66 \\
B.G1-3 & $13,06 \mathrm{~b}$ & 77,06 \\
\hline
\end{tabular}

Keterangan : Angka yang diikuti huruf yang sama menunjukkan tidak berbeda nyata berdasarkan uji Duncan Multiple Range Test pada taraf 5\%. * tidak terjadi penekanan penyakit 
Kemampuan daya hambat bakteri Bacillus spp. terhadap S. rolfsii secara umum dibawah 50\%. Kemampuan daya hambat yang tinggi secara in vitro menunjukkan bahwa isolat-isolat tersebut memiliki sifat antagonis terhadap cendawan patogen. Hal tersebut berkaitan dengan kemampuan antagonis setiap isolat bakteri dalam memproduksi enzim ekstraseluler seperti kitin, protase, dan selulase. Selain produksi enzim ekstraseluler, kemampuan antagonis suatu bakteri rizosfer juga dipengaruhi oleh kemampuan memproduksi siderofor (Khaeruni et al., 2010). Kitinase mendegradasi kitin yang merupakan komponen penyusun dinding sel cendawan seperti Fusarium oxysporum, Rhizoctonia solani, dan S. rolfsii (Raaijimaker et al., 2008).

Persentase pree-emergence damping off pada tanaman kedelai yang telah diberikan perlakuan isolat Bacillus spp. lebih tinggi dibandingkan dengan fungisida. Terdapat beberapa isolat Bacillus spp. yang menunjukkan persentase pree-emergence damping off lebih rendah dibandingkan dengan kontrol sakit. Persentase pree-emergence damping off terendah terjadi pada perlakuan isolat B.SM-15 dan B.SM-2 yaitu sebesar $33,78 \%$ dengan penekanan penyakit 34,49\%. Hasil tersebut dapat dikarenakan kemampuan kolonisasi bakteri pada lingkungan. Menurut Yuliar (2008), jumlah bakteri yang semakin banyak akan menghasilkan jumlah metabolit sekunder yang semakin banyak juga, sehingga akan meningkatkan penghambatan bakteri terhadap patogen. Penggunaan agens PGPR sebagai biokontrol dengan hasil yang maksimal masih sulit dikarenakan kemampuannya dalam beradaptasi (Anisa, 2011). Serangan cendawan patogen sangat cepat sementara kolonisasi bakteri belum baik, sehingga cendawan patogen lebih awal mengkolonisasi dari agens biokontrol, hal ini mengakibatkan agens biokontrol belum mampu mengaktifkan sifat antagonisnya.

Persentase post-emergence damping off pada tanaman kedelai dengan perlakuan bakteri Bacillus spp. lebih rendah dibandingkan dengan kontrol sakit. Isolat B.G1-3 merupakan perlakuan terbaik untuk menghambat penyakit post-emergence damping off pada tanaman kedelai dengan penekanan penyakit sebesar 77,06\%. Kesesuaian aplikasi agens hayati dapat mempengaruhi tingginya kejadian penyakit pada tanaman. Hal ini berkaitan dengan penelitian yang telah dilakukan oleh Safrina (2012), bahwa perlakuan perendaman benih dapat mempengaruhi munculnya kejadian penyakit dan laju pertambahan tinggi tanaman kedelai. Perlakuan benih dengn PGPR akan menghasilkan pembentukan koloni PGPR sedini mungkin sehingga dapat mencegah pembentukan koloni patogen pada akar (Khalimi, 2009). Selain itu rizobakteria dapat menghambat 
patogen tanaman secara langsung dan tidak langsung. Menurut Astuti (2007), bakteri Bacillus sp. yang diisolasi dari rizosfer tanaman kedelai mempunyai potensi sebagai pemacu pertumbuhan tanaman dan dapat mensintesis IAA, melarutkan fosfat, menghasilkan siderofor, serta mampu menghasilkan senyawa antifungi. Produksi siderofor, antibiotik dan $\mathrm{HCN}$ oleh rizobakteria mampu menurunkan pertumbuhan fitopatogen.

Hasil penelitian ini menujukan bahwa persentase rebah kecambah pada tanaman kedelai sebelum muncul kepermukaan tanah (pree-emergence damping off) terendah sebesar 33,78\% dan tertinggi sebesar 59,3\%. Penyakit rebah kecambah setelah muncul dipermukaan tanah (post-emergence damping off) persentase tertinggi mencapai 27,82\%. Permukaan akar merupakan tempat yang kaya nutrisi sehinga dapat menarik keragaman mikroorganisme. Sehingga persaingan untuk mendapatkan nutrisi dan tempat adalah mekanisme mendasar PGPR melindungi tanaman dari fitopatogen (Duffy, 2001). Kemampuan bakteri untuk beradaptasi dan kolonisasi, dapat disebabkan dari sifat bakteri yang meliputi motilitas kemotaksis terhadap eksudat benih dan akar serta produksi komponen spesifik untuk melekat pada akar. Kolonisasi akar dengan inokulasi bakteri adalah langkah penting dalam interaksi antara bakteri yang menguntungkan dan tanaman inang.

Menurut Abidin et al. (2015) perlakuan bakteri antagonis isolat Bacillus spp. mampu menekan penyakit rebah kecambah. Seluruh perlakuan dengan pemberian bakteri Bacillus spp. dapat menekan penyakit rebah kecambah post- emergence damping off pada tanaman kedelai secara in planta. Mekanisme terpadu yang diduga dapat menekan kejadian penyakit adalah potensi kitinase, $\beta$ - 1,3 glukanase, siderofor, kemampuan kompetisi agens, antibiotik, enzim peroksidase dan potensi lainnya (Tahar, 2009).

\section{KESIMPULAN DAN SARAN}

Berdasarkan hasil penelitian yang telah dilakukan, maka dapat diperoleh kesimpulan bahwa :

1. Terdapat beberapa isolat bakteri Bacillus spp. tidak dapat menekan penyakit rebah kecambah sebelum muncul kepermukaan tanah pada tanaman kedelai.

2. Semua isolat bakteri Bacillus spp. mampu menekan penyakit rebah kecambah setelah muncul kepermukaan tanah pada tanaman kedelai, isolat yang terbaik untuk menekan 
3. penyakit rebah kecambah setelah muncul kepermukaan tanah adalah isolat B.G1-3 di isolasi dari tanah yang ditanamani Varietas Dega di Desa Kota Baru Kec. Geragai.

4. Pemberian bakteri Bacillus spp. dapat menekan penyakit rebah kecambah sebelum muncul kepermukaan tanah sebesar 21,56\% sampai 34,49\%, dan penyakit rebah kecambah setelah muncul kepermukaan tanah sebesar 51,14\% sampai 77,06\%.

\section{Saran}

Berdasarkan hasil penelitian yang telah dilakukan maka penulis memberikan saran yaitu perlu dilakukan penelitian lanjut untuk mengetahui cara terbaik aplikasi bakteri Bacilus spp. untuk mengendalikan penyakit pada tanaman.

\section{DAFTAR PUSTAKA}

Abidin Z, LQ Aini, dan AL Abadi. 2015. Pengaruh bakteri Bacillus spp. dan Pseudomonas sp. terhadap pertumbuhan cendawan patogen $S$. rolfsii Sacc. penyebab penyakit rebah semai pada tanaman kedelai. J. HPT Vol. 3 No. 1.

Adisarwanto T. 2008. Budi Daya Kedelai Tropika. Jakarta (ID): Penebar Swadaya.

Anisa Y. 2011. Pengaruh mulsa dan PGPR terhadap insidensi penyakit busuk pangkal batang (S. rolfsii Sacc.) pada tanaman kedelai $(G$. $\max (\mathrm{L})$ Merill) [skripsi]. Institut Pertanian Bogor. Bogor

Astuti RP. 2007. Rizobakteria Bacillus spp. asal tanah rizosfer kedelai yang berpotensi sebagai pemacu pertumbuhan tanaman. [Tesis]. Sekolah Pascasarjana Institut Pertanian Bogor. Bogor. Badan Pusat Statistik (BPS). 2016. Produktivitas Kedelai Menurut Provinsi (kuintal/ha),1993-2015. https://www.bps.go.id (diakses pada 12 Mei 2017).

Barnett HL. 1960. Illustrated Genera of Imperfect Fungi. $2^{\text {nd }}$ edition. Burgess Publishing Co. Minneapolis, MN.

Duffy BK. 2001. Competition in encyclopedia of plant pathology, Eds. O. C. Maloy, and T.D. Murray, pp. 234-24. John Wileyand Sons, Inc.: New York, USA.

Eliza, A Munif, I Djatnika dan Widodo. 2007. Karakter fisiologis dan peranan antibiosis bakteri perakaran graminae terhadap fusarium dan pemacu pertumbuhan tanaman pisang. Jurnal Hortikultura. Vol. 17 No. 2.

Hatmanti A. 2000. Pengenalan Bacillus spp. Balitbang Lingkungan Laut, Puslitbang Oseanologi-LIPI, Jakarta.Vol. XXV, No. 1, $2000: 31-41$

Khaeruni A, GAD Sutariati, dan S Wahyuni. 2010. Karakterisasi dan uji aktivitas bakteri rizosfer lahan ultisol sebagai pemacu pertumbuhan tanaman dan agensia hayati cendawan patogen tular tanah secara in vitro. Jurnal HPT Tropika. Vol. 10 No. 2: $123-130$. 
, dan A Rahman. 2012. Penggunaan bakteri kitinolitik sebagai agens biokontrol penyakit busuk batang oleh $R$. solani pada tanaman kedelai. Jurnal Fitopatologi Indonesia. Volume 8, Nomor 2, Hal. 37-43

Kloepper JW, RR Ubana, GW Zehnder, JF Murphy, E Sikora dan C Fernandez. 1999. Plant root-bacteria interactions in biological control of soil borne diseases and potential extension to systemic and foliar diseases. Austral Plant Pathol 28:21-26.

Nawangsih AA, T Widjayanti, dan Y Anisa. 2014. Kelimpahan bakteri rizosfer pada sistem pht-biointensif serta kemampuan antagonismenya terhadap

S. rolfsii pada kedelai. Bogor. Jurnal HPT Tropika. Vol. 14 No.2 : 110-120.

Nogueira MA, G Diaz, W Andrioli, FA Falconi dan JR Stangarlin. 2006. Secondary metabolites fro Diplodia maydis and S. rolsfii with antibiotic activity. J Braz Microbiol 37:14-16.

Raaijmaker JM, Paulitz TC \& Steinberg C. 2008. The rhizosphere : a playground and battlefield for soilborn pathogens and benefecial microorganism. Plant Soil 10: 1007-1014.

Safrina CPA. 2012. Keefektifan plant growth promoting rhhizobacteria sebagai pemacu pertumbuhan dan penghambat penyakit busuk pangkal batang (S. rolfsii Sacc.) pada kedelai. Institut Pertanian Bogor. Bogor.

Sastrahidayat IR, Syamsuddin Djauhari, dan Nasir Saleh. 2007. Pemanfaatan pellet mengandung saproba antagonis dan endomikoriza (vam) untuk mengendalikan penyakit rebah semai ( $S$. rolfsii) dan meningkatkan produksi kedelai. Laporan Hasil Penelitian Kerjasama Kemitraan Penelitian Pertanian dengan Perguruan Tinggi (KKP3T). Fakultas Pertanian, Universitas Brawijaya. Malang. $89^{\text {th }}$.

Tahar. 2009. Rizobakteria Pseudomonas sp. dan Bacillus spp. toleran asam aluminium sebagai pemacu pertumbuhan tanaman dan pengendali fungi patogen akar tanaman kedelai. [Tesis]. Sekolah Pascasarjana Institut Pertanian Bogor. Bogor.

Thompson DC, BB Clarke, dan DYKobayashhi. 1996. Evaluation of bacterial antagonis for reduction of summer patch symptoms in Kentucky bluegrass plant Dis. 80 : 856-862.

Yuliar. 2008. Skrining bioantagonistik bakteri untuk agen biokontrol Rhizoctonia solani dan kemampuannya dalam menghailkan surfaktin. Biodiversitas Vol. 9 No. 2. 